Springer2018-Section5REVISED

\title{
Working and Learning from a Bernsteinian Perspective
}

Dr Sai Loo, UCL Institute of Education, University College London, England. E-mail: sai.loo@ucl.ac.uk

\begin{abstract}
Table 1)
This chapter focuses on the working and learning of teachers' professional/occupational practices. These practices occur in the teachers' specific areas of professional sectors such as the airline industry, equine sector and fashion and textiles. The deliverers teach on work-related programmes in the vocational/technical and vocational education and training (TVET)/pre-university academic level.
\end{abstract}

In studying the working and learning of the teachers' professional practices, this chapter uses a conceptual framework that relies on a dual professional concept (Handal, 1999) at the initial stage and this contribution centres on occupational practices and not the pedagogic activities of the teachers. Acquisition of knowledge theoretical frameworks relates to those by Clarke and Winch (2004), Eraut (2004), and Winch (2014). Turning to the application of knowledge, the relevant conceptual frameworks include those by Barnett (2006), Evans et al. (2010), Kahneman (2012), Kemmis and Green (2013), and Evans (2016).

The empirical evidence is based on data from a larger project (Loo, 2018). The research methodologies include quantitative and qualitative research methods. These are questionnaire survey, one-to-one semi-structured interviews and documentary evidence.

Using empirical data, examples of how types of know-how acquired by participants in gas servicing, health and social work, fashion and textiles and equine industries are discussed. The participants' perspectives of their use of know-how are also delineated using the above theoretical frameworks to provide deep insights into how they perform their roles in the respective work areas. The conclusion section offers contributions and implications of this study.

\section{Keywords}

Vocationalism; Teachers' knowledge; Working; Learning; Occupational practices

\section{Introduction}

This chapter contributes to the 'Vocational learning' section and specifically, it focuses on the vocational learning and working of teachers in their occupational settings. These teachers in the post compulsory or further education (FE) sector, in addition to delivering work-related or vocational programmes, also have experiences of working in their relevant occupations. Using empirical data from a larger project (Loo, 2018), the data on teachers of vocational or technical and vocational education and training (TVET) is used in this chapter. TVET is used for two reasons. The first is that it is an internationally recognised term (United Nations Educational, Scientific and Cultural Organization, 2012) that features programmes that are related to work such as health and social care, travel and tourism (e.g. airline studies) and gas fitting. The second reason is to avoid the 'English contexts' where the past research has been hampered by 
issues such as the academic-vocational division and socio-cultural dimensions (Loo and Jameson, 2017).

The FE sector in England has a diverse range of teaching settings. The teaching settings include adult and community learning providers, armed and uniformed services, commercial organisations, FE colleges, independent training providers, industry, prisons and offender learning institutions, public sector organisations, specialist colleges, and voluntary and community sector organisations (Education and Training Foundation, 2014). The learners are 16 plus, adult and lifelong learners and a significant percentage of them have diverse learning abilities. One of the characteristics of this sector is it offers further learning opportunities for students from the compulsory education sector. The other characteristic is over seventy-five percent of the provisions are work-related. The popular areas include Visual and Performing Arts and Media, Health, Social Care and Public Services, Foundation Programmes, Business Administration, Management and Professional (at higher education academic level), and Hospitality, Sports, Leisure and Travel (Frontier Economics Limited, 2014, Table $15)$.

This chapter investigates how and what the TVET teachers need to carry out their occupational practices in their respective areas. Using the empirical data of the larger project (Loo, 2018), the TVET occupational areas include the airline industry, equine sector, fashion and textiles, gas services, and health and social care. To study this, the chapter is structured into five sections, following the introduction. The next section delineates the relevant theoretical frameworks, and the third section offers details of the relevant project. The fourth section includes a discussion of the findings, and the final section provides a summary, contributions and implications of this study.

\section{Conceptual frameworks of working and learning}

This section on the theoretical frameworks investigates the relevance of knowledge concerning learning and work. The relevant knowledge is then discussed concerning its application in work settings. This section uses recontextualization processes to offer insights into how knowledge may be understood regarding its relevance to work and its utility concerning work practices. Recontextualization may be viewed as the selection, relocation and refocus of knowledge (Bernstein, 1996), which is modified and made relevant to a specific occupation.

Post-Bernsteinian researchers such as Barnett (2006), Evans et al. (2010), and Loo $(2012,2014)$ offer additional forms of this process. Barnett (2006) acknowledges the relevance of the disciplinary knowledge in work conditions. His reclassificatory recontextualization process relates to the utility of disciplinary knowledge such as physics as a 'toolbox of applicable knowledge' with strategies to satisfy the demands of occupational practice (Barnett, 2006, p. 147). He offers another process which he calls 'pedagogic recontextualization' for teaching purposes. However, he is short on the details of the two recontextualization processes. Evans et al. (2010, p. 254) develop the recontextualization concept further to include the "subject-based and work-based aspects of a curriculum and learning programme" where different forms of know-how are selected and relocated in "different sites of learning in colleges and workplaces". They include skills, capabilities in addition to disciplinary knowledge and suggested four recontextualization processes. These are content recontextualization, pedagogic recontextualization, workplace recontextualization and learner recontextualization. 
With content recontextualization process, codified forms of knowledge of disciplinary, procedural and work process are selected for use in curriculum and teaching. Pedagogic recontextualization relates to the selected know-how and its application in teaching, learning and assessment. Workplace recontextualization offers insights into how knowledge may be applied in workplace contexts. Learner recontextualization concerns the learner's acquisition and application of knowledge. Evans et al. offer nuanced insights of the acquisition and application of know-how in pedagogic and work contexts. However, from a temporal dimension, it is not clear how the two codified knowledge of disciplinary and work-related are acquired. Also, there are insufficient details of the possible interactions between explicit and tacit know-how. Evans (2016) clarifies this point in her descriptions of 'knowledgeable practice' where it infers forms of learning such as informal and peer learning. It assumes varieties of know-how such as explicit (e.g. disciplinary knowledge) and tacit (e.g. interpretation of work activity), skills (e.g. suturing skills in nursing) and abilities (e.g. problem-solving). Loo (2012) explicitly suggests that tacit knowledge, such as those from work settings, may be recontextualized along with explicit forms. He later offers a new form of recontextualization - Ongoing Recontextualization - involving disciplinary know-how between subject areas and between disciplinary/theoretical knowledge and every day or tacit experiences (Loo, 2014, p. 352). He develops further "Bernstein's fine division of his horizontal pedagogic discourses and tacit 'vocational elements' of horizontal knowledge structures of the vertical pedagogic discourses, and Barnett's reclassificatory recontextualization" (Loo, 2018, p. 40). In short, Loo advocates that explicit and tacit forms of knowledge may interact and are changed as a result.

A worker, who may eventually become a teacher of TVET programmes, needs to acquire the relevant disciplinary know-how that is related to that occupation. This acquisition may be exemplified by a person learning to become a gas fitter. He/she needs to know about physics relating to gas expansion etc. However, the knowledge of how a particular type of gas such as carbon monoxide behaves is not sufficient. This know-how needs to be relevant to gas fitting. It is through the process of Content Recontextualization where the disciplinary knowledge of physics is selected and relocated to meet the needs of gas fitting.

Bernstein offers three modes of the organisation of the vertical knowledge. Bernstein viewed this knowledge as explicit and codified and might be organised into singulars, regions and generic. For him, singulars are disciplinary knowledge such as "physics, chemistry, history, economics and psychology" (Bernstein, 1996, p. 65). Regions are constructed by recontextualizing singulars into larger units, which operate in fields such as engineering and architecture (Bernstein, 1996). Generic mode relies less on academic or applied academic disciplines, and vocational know-how may be classified in this mode as part of a "skill task, practice or even area of work" (Bernstein, 1996, p. 66-67). This radical 'generic' mode offers insights into learning of TVET programmes such as airline studies, equine studies, fashion and textiles and gas fitting. These occupations are included in the list of occupational areas in Table 1.

Once the disciplinary knowledge is made relevant via the Content Recontextualization process, it becomes occupational knowledge. According to Eraut (2004) and Winch (2014), this type of knowledge also includes knowledge of procedures, skills (e.g. interpersonal and intrapersonal that are tacit), techniques, transversal abilities, project management abilities, personal capabilities and occupational awareness. In short, 
occupational know-how is more than recontextualized disciplinary knowledge from the singular mode. It consists of a worker's past knowledge (of theoretical and procedural knowledge and experiences), understanding (of work and specific project contexts), skills (technical and non-technical), dispositions and the perceptions of the work settings the workers operates. This know-how may be explicit or tacit (Collins, 2010; Nonaka and Takeuchi, 1995).

The occupational knowledge along with work knowledge (which is viewed as knowledge that is related to the work environment/organisation in which the worker is situated) are then recontextualized via the Occupational Recontextualization process to become applied occupational knowledge. This work knowledge may include processes, protocols and mentoring systems, which are specific to that work environment (Evans et al., 2010). This is after the second recontextualization process that this modified know-how may be applied in work activities.

In addition to the recontextualization processes, there are concepts that provide additional insights into how a worker may apply the modified know-how to work practices. These concepts include 'Knowledgeable practice' (Evans, 2016). It is developed through formal and informal learning in the work environments and beyond. 'Practice architecture' (Kemmis and Green, 2013) is viewed as the 'sayings', 'relatings' and 'doings' in work organisations, institutions and settings, and 'Systems 1 and 2' (Kahneman, 2012) where the former is intuitively based on past occupational experiences. The latter system is based on rational and cognitive interactions.

'Knowledgeable practice' is developed through learning at the workplace, observations of others and includes support structures such as mentorship (Evans, 2016). This concept offers a way of understanding the occupational practice. It supports the sociocultural impact on a worker's learning including collaborative working with people in the work settings. One may also suggest that this approach infers informal and peer learning and assumes a wide perspective of knowledge to include explicit and tacit forms along with occupational experiences, skill sets, abilities and dispositions. These perspectives of practices offer insights into how a TVET worker may acquire and apply forms of knowledge in the work environments.

'Practice architecture' is used as a concept to understanding teachers' pedagogic activities in work-related provisions. Kemmis and Green (2013) advocated that these teachers with occupational experiences can provide insights into the micro-workings which use past work-related experiences. Practice architecture uses 'sayings, doings and relatings' to help understand the practices. They argue that "these practice architectures are constructed shapes practice in its cultural-discursive, social-political and material-economic dimensions, giving substance and form to what is and can be actually said and done by, with and for whom" (Kemmis and Grootenboer, 2008, p. 57). Like knowledgeable practice above, practice architecture acknowledges the sociocultural dimensions. The former concept perhaps offers a more micro-delineations of working in an occupational setting focusing on the deliberations - verbal, actions and cognitions - concerning work practices. However, neither of the concepts provides understandings of decision-making.

Kahneman (2012) offers 'System 1 and 2' to understanding how a worker decides a course of action. For him, System 1 is responsive to a specific need for decision-making 
such as responding to an already drunk airline passenger's request for more alcohol in the airline industry. Little effort is involved and is based on skills or heuristics from past occupational experiences. System 2 is slower in its reaction to a particular situation and is based on conscious and rational approach. It needs continuous professional training, and with this, there are implications for financial and human resourcing. The two systems are connected. Kahneman's concepts provide a way of understanding decision-making processes, which have varying speeds of reaction and potentialities of judgement errors. These approaches have traction on how TVET workers decide on their courses of action.

It is through these frameworks that know-how is acquired and applied in work settings by a worker. This conceptual framework is not necessarily linear or one-directional but is dynamic and process-driven (Chaiklin and Lave, 1996; Cole, 1996).

It involves contexts of sociological forces around temporal dimensions such as work conditions, forms of teaching institutions, academic level of the taught provision, types of learners and nature of the occupation. Movements may occur between these contexts and can affect the acquisition and utility of occupational know-how via the recontextualization processes in specific learning and work conditions.

These concepts will be referred to in the discussion section below using analysed data. Before this, the next section offers salient methodological details.

\section{Project details}

The empirical data that is used in this chapter relates to a larger project (Loo, 2018) where the main research questions centre on the nature of occupational pedagogy and the manner in which the related know-how is acquired and employed in the pedagogic activities of work-related programmes. The project used the term 'occupational pedagogy' to denote teaching and learning practices across the three academic levels of TVET, first-degree/higher vocational and professional education. It draws on 21 purposive teachers/participants, seven from each of the three levels. In this chapter, seven of these participants (P1-7) (Table 1) teach on the TVET programmes of airline studies, art (painting and printmaking, equine studies, fashion and textiles, gas services, and health and social care. The research methods used included a questionnaire survey and semi-structured interviews. The survey elicited details such as gender, age, pedagogic, occupational and life experiences, and academic and professional qualifications. The qualitative data from the interviews offered thick descriptions of their professional practices. Both the data capture involved pilot studies in fine-tuning the survey, interview questions, and procedures. Documentary evidence such as programme specifications was also gathered, and these three data sources were analysed and triangulated using generated codes, identified phrases, patterns, themes as part of the thematic analysis (Robson, 2002). The principal and only investigator used narrative analysis (Robson, 2002) where the relevant teachers' descriptions were employed in the discussion and findings section to illustrate and provide further insights. It is not the intention to include details of all seven of the participants but merely to focus on those participants, whose occupational experiences are pertinent to the aims of this chapter.

\section{Findings and discussion}

This penultimate section uses the relevant analysed data to discuss the participants' perceptions of the sources and types of know-how and how these relate to their 
occupational practices. The structure follows the same format as in the literature review section of critiquing the sources and types and applications of the related know-how.

\section{Acquisition}

P2 (Table 1), a male lecturer in his 50s at an FE college, has been teaching gas services provisions for 15 years. He worked in the gas service industry as an engineer. From a disciplinary knowledge, he views the 'basic knowledge of physics, mathematics and chemistry' as relevant to this industry. In particular, the theoretical knowledge of combustion equation and gas flows as particularly relevant to his sector. However, the theoretical knowledge is not as in-depth as those required at "Advanced" levels, and the emphasis is on the "hands-on" dimension concerning his occupation practice. In the health and social care sector, P3, a female lecturer with eight years full-time teaching experiences, indicated that "basic knowledge of biology, anatomy, psychology" is required. Additionally, her "practitioner's experiences and life experiences of secure family life" are also relevant to her occupational work. For an equine industry, P5 with the industrial or occupational experiences suggested that "physics, anatomy, psychology, numeracy and occupational knowledge" are all necessary for working in this sector. In addition to disciplinary know-how, there is also occupation-specific "knowledge of show jumping, dressage, and theory of horses getting into a horsebox". Other industry-specific know-how includes numeracy such as 2.5 kilos of oats and barley are consumed daily by a horse, and a horse has 36-45 heartbeats per minute. However, he admits that "the equine sector regarding the types and sources of knowledge are at the coal face" and much more research is still needed.

The above delineations offer a range of sources and types of knowledge. P2, P3 and P5 refer to theoretical knowledge from the disciplines (Becher, 1994; Smeby, 1996), which Bernstein (1996) refers to as 'vertical discourse'. The source of this knowledge is from the disciplines. Some of the participants use 'basic knowledge' to describe the knowledge of disciplines. They imply that these forms of theoretical knowledge are used as starting blocks for their occupations. The participants also mentioned that other types of know-how are relevant in their occupational practices. The term, 'occupational relevance' offers an entry point into how they relate theoretical knowledge to their work. P2 uses "hands on" in a similar fashion.

The suggested conceptual framework uses Content Recontextualization as a process by which knowledge from other sources such as the disciplines of physics, chemistry, biology and mathematics are re-applied for their occupational relevance. So, in P2's example, certain aspects of physics about gas fitting/services are chosen as of occupational relevance. This theoretical knowledge is recontextualized, that is selected, relocated and refocused (Bernstein, 1996) to make the knowledge relevant to gas fitting. Here, theoretical knowledge of combustion combustions and gas flows from physics is selected from the curriculum. This is relocated and refocused to make it relevant and applicable to gas services so that a worker in this industry can understand the theoretical principles as well as understanding the relevance to the gas fitting of a boiler in a household environment. This process is called Content Recontextualization where parts of the specifications are selected and made relevant to the occupation. A civil engineer who is involved in sewage works may use the same disciplinary know-how but for the particular occupational practice that is specific to that project. One may argue that this Content Recontextualization process is different for different occupations and occupational practices. 
From a curriculum formation or development perspective, the level of theoretical knowledge necessary for occupational practices may not be at the same level of those merely acquiring the knowledge of that discipline. So a person studying 'A' physics may have a higher level of the subject compared to a student of gas services. However, one may argue that for the gas fitter learner, he/she requires further cognitive processing to understand the selected theoretical know-how and then relate it to the industrial requirements, which may require further cognitive processing. The cognitive processing uses Learner Recontextualization (Evans et al., 2010).

This application of theoretical knowledge is supported by Clarke and Winch (2004, p. 519) which they see as "applicable theory and practice appropriately informed by theory". Eraut (2004), in a similar vein, views disciplinary knowledge as the springboard to work practices and Winch's (2014) professional knowledge typology also subscribes to 'systematic knowledge' as theoretical know-how that is applied to occupational contexts. All three theorists advocate the relevance of theoretical knowhow to work contexts. What might be missing was the acknowledgement that the theoretical knowledge needs to be made relevant via a process of Content Recontextualization where parts of a specification are chosen and relocated to specific occupational needs.

In addition to the theoretical knowledge, the participants also refer to other sources of know-how. P3 refers to her "practitioner's experiences and life experiences of secure family life", and P5 mentions his occupation-specific know-how of show jumping, dressage, horse's food consumption etc. These are sources of know-how, which relate to Eraut's (2004) methodological knowledge, practical skills and techniques and general knowledge. Winch's (2014) professional knowledge typology also has overlaps with Eraut's and the participants' knowledge sources especially with his technique, skill, transversal abilities (such as planning and coordinating a dressage event), and project management abilities (such as fitting a boiler in a house). These know-how, skills, abilities and capacities are pertinent to the participants' specific work practices. They are front-loaded base on the seven participants' experiences. However, this does not mean that in theory, occupational know-how may not be acquired while in occupational settings (Hager, 2004) rather than a front-loaded scenario, as exemplified by the seven participants.

In addition to the sources of know-how, there are types too such as explicit and tacit. Explicit types may include the disciplinary know-how such as physics and biology. These can be acquired in a formal programme such as the Level 3 National Vocational Qualification (NVQ) in gas servicing, a Level 3 Business and Technology Education Council (BTEC) programme in fashion and design, and travel and tourism. Knowledge sources from the Internet may also be codified. Tacit sources may be from individuals or through collaborations (Nonaka and Takeuchi, 1995; Collins, 2010). They may include a participant's occupational experiences, colleagues' experiences, occupational skills (e.g. the necessary pressure to turn a valve in gas fitting and steer a horse for dressage). How the occupational know-how is utilised is discussed in the next section.

\section{Applications}

This section offers the perspectives of two participants - P2 and P5 - who are practitioners in the gas services and equine industries respectively. They provide 
insights of their use of know-how concerning their occupational practices, and their relevance to the concepts of 'knowledgeable practice' (Evans, 2016), 'practice architecture' (Kemmis and Green, 2013) and 'Systems 1 and 2' (Kahneman, 2012).

$\mathrm{P} 2$ recounted the incident as a gas service engineer (for six years) with a national gas provider in the private sector:

on a cold winter's day being asked to go to a house in the street next to my house as there was a smell of gas. There was no gas leak inside the house on inspection, and so the leak must be from the outside. I radioed to Bolton (where the office was) and left it and further asked the outside distribution lads to check it out. On my return from my other duties, I passed the inspected house, and the front door was blown off along with the windows. Since that incident, the house had not been lived in.

(Loo, 2018, p. 58)

P5 worked in the equine industry for over 20 years as the owner of riding schools, designer of showjumping courses, and took part in competitive showjumping. Before entering the horse industry, he trained as an accountant. He acknowledged the need for the equine industry to undertake further research. These include the intricate synergy between the horse and rider using the Pegasus system of cameras and global positioning system (GPS) to track the anatomical movements of the horse and rider. They also include the enhancement of safety features in the sector as advocated in France and the impact of racecourses on both the horse and the rider.

From the perspective of the Occupational Recontextualization, P2 used his occupational knowledge (via the Content Recontextualization) of physics and chemistry knowledge of gas flows, gas expansions and combustion that is occupationally relevant to gas servicing to inspect the house internally. On satisfying himself that the gas leak was not from the house, he concluded that the leak was from the outside. This decision was illustrative of Kahneman's System 2 where P2's past professional experiences, cognitive processes and the specific contexts of the setting were used in arriving at a professional judgement to discount the house as a potential source of the gas leak. Practice architecture of 'sayings, doings and relatings' (Kemmis and Green, 2013) may also be featured here. P2 conveyed ('sayings') his professional evaluation to the head office before moving to another case. He adhered to this procedural aspect of the company's system ('doings'). His message should have been conveyed to the external distribution department of the company in the follow-up process ('relatings). P2 as a professional practitioner carried out the company's procedures. This aspect of the specific occupational practice also has resonance with another part of the Content Recontextualization, which is work knowledge. In addition to applying his recontextualized disciplinary knowledge, i.e. occupational knowledge, P2 also used his knowledge of the organisational system of health and safety procedures and established lines of communications to carry out his professional responsibilities.

In a slightly tangential perspective, Evan's (2016) knowledgeable practice concept provides insights into P2's learning of his occupational experiences by focusing on the development of his learning by observing and being mentored by his peers and learning about specific aspects of his work through different occupational experiences. The 
combination of his disciplinary/theoretical knowledge along with his learning experiences while at work provided him with a unique data of knowledge, experiences, skills and abilities (Eraut, 2004; Winch, 2014) to refer to and apply to the specific professional setting such as the one, which was recounted above.

Turning to P5, he offers a different perspective to that of P2's. P5 ran his riding schools and designed showjumping courses. Different knowledge, abilities, and skill sets are needed. He needs to have a vision for setting up a riding school such as its location, potential catchment area and clients, and the rationale for this undertaking. His earlier training in accountancy would have been useful in ascertaining the financial viability of such an undertaking through his use of cash flow and budgeting know-how. Leadership, planning, project management abilities, focus, self-motivation and risktaking are skills, abilities and capacities (Eraut, 2004; Winch, 2014) that are needed to start his riding schools. Also, P5 needs to establish a system for his school such as health and safety procedures especially if young people are involved, procedural, administrative and financial systems. An example of this is the purchase and payment of food for the horses. A horse consumes, on average, two and a half kilos of oats and barley feeds per day. This information will be helpful in the ordering of feed for the horses, and the choice of supplier and its payment require a system in place. These systems constitute work knowledge and together with the necessary occupational know-how will enable P5 to relocate and modify via Occupational Recontextualization process to facilitate him in his occupational activities.

He uses his occupational know-how of competitive horse eventing experiences, knowledge of showjumping courses and the equine industry to enable him to design a showjumping circuit. This know-how may include his experiences as a competitive rider of approaching jumps, the use of support teams in getting horse and rider ready for such an event, the required feed leading up to this and the exercises for both horses and riders to acquaint with a specific course. All these experiences will enable P5 to design a circuit for an appropriate level. It will involve details of the type of ground, distances leading up to and after the hurdles, the dimensions and structures of the hurdles and much more. From the perspective of Occupational Recontextualization, he draws on not only his past professional experiences but also his sense of a vision for a circuit, which fits the requirements of a specific event or funder, and his leadership abilities to sell his idea. From the implementation aspects, he needs project management abilities, collaborative capacities, patience and the ability to follow it through to completion. The know-how, like the ones stated earlier, is both codified and tacit (Polanyi, 1966; Nonaka and Takeuchi, 1995; Collins, 2010). Examples of codified forms are the occupational knowledge derived from the disciplines such as biology and mathematics. The tacit ones include occupational experiences, knowledge of showjumping courses and collaborative working with related stakeholders. These tacit varieties may broadly be classified as individual and collaboration-related as investigated by Nonaka and Takeuchi (1995) and Collins (2010).

P5's occupational activities may be connected to the three concepts of 'knowledgeable practice' (Evans, 2016), 'practice architecture' (Kemmis and Green (2013) and 'systems 1 and 2' (Kahneman, 2012). Examples of the first concept include the setting up and implementation of a mentoring system in P5's riding schools, and observations of the impact of riders and horses at a showjumping event. Examples of the second concept are how health and safety features are conveyed to his staff and users in the 
riding school, and the implementation of these guidelines concerning the wider industry and its related organisations such as the British Horse Society and the World Equestrian Authority. Finally, with the third concept, his professional experiences in approaching equestrian jumps in a competition may be viewed from system 1 or 2 perspectives, the former has a quick response and the latter a considered response based on reflected evaluations of similar situations.

The above discussions focusing on the occupational activities of P2 and P5 provide contrasting insights into the types, sources and applications of occupational and applied occupational know-how.

Regarding sources and types of know-how, P2 and P5 use disciplinary or 'basic' knowledge of physics, mathematics and chemistry for gas fitting, and physics, anatomy, psychology and numeracy for the equine industry respectively. However, these basic knowledge needs to be 'made relevant' to the specific occupations. Similarly, the level of disciplinary know-how is not the same as its academic equivalent programme. Thus for P2, the level of physics necessary for gas fitting is not as high as the equivalent Advanced level course. However, it does not mean that the training is of lesser quality, as the disciplinary knowledge needs to be recontextualised via the Content Recontexualization process to give the know-how the 'occupational relevance' for eventual application. Additionally, the participants' occupational and life experiences along with occupational know-how such as knowledge of showjumping, dressage are needed, especially in the equine sector where the lack of research meant that, according to P5, "the types and sources of knowledge are at the coal face." Also, there are the explicit and tacit forms of know-how. The disciplinary ones represent the explicit variety. The tacit variety (Polanyi, 1966; Nonaka and Takeuchi, 1995; Collins, 2010) includes occupational experiences, experiences from colleagues; skill sets, e.g. the necessary pressure to turn a valve in gas fitting, and steering a horse in a dressage event. It also includes collaborative working with the related stakeholders. The two studies also offer insights into the explicit and tacit forms of know-how as well as a wider delineation of knowledge (such as abilities, capacities, experiences, skill sets, and theoretical knowledge) as espoused by Eraut (2004) and Winch (2014).

P2 and P5's recounted their real-life experiences of a gas leak in a house nearby to P2's, and the managing of riding schools, designing of and competing in showjumping events, and accountancy training respectively. P2 used his disciplinary and occupational know-how to inspect the gas leak (via the Content and Occupational Recontextualization processes. He decided to discount an internal gas leak (Kahneman, 2012) and contacted the head office to look into an external leak before going onto another job (Kemmis and Green, 2013). P5 has managerial experiences (Eraut, 2004; Winch, 2014) where he implemented health and safety procedures in his riding schools with specific adherence to the equine industry guidelines (Kemmis and Green, 2013), and organized mentoring systems to train staff (Evans, 2016). These 'knowledgeable practices', 'practice architectures' and 'Systems 1 and 2 decision making' processes added another layer of understanding of knowledge applications.

However, these complex interactions of know-how occur constantly and are continually modified as a result of specific occupational settings. These Ongoing Recontextualization processes as propounded by Loo (2018) involve the following. They are forms of disciplinary knowledge, 'theoretical' and 'everyday' knowledge 
(Bernstein, 1996), explicit and tacit varieties of know-how (Nonaka and Takeuchi, 1995), and between abilities, capacities, experiences, and skill sets (Eraut, 2004; Winch 2014). Examples of these were discussed earlier. This ongoing process, according to Loo, changes the characteristics of the know-how from the users' perspectives (such as P2 and P5). For the users, they can become conscious and unconscious varieties of know-how, where the disciplinary knowledge (explicit and conscious, e.g. knowledge of physics) combined with occupational experiences and practices (tacit to a degree) may become unconscious and instinctive in decision-making. Similarly, a solving of an occupational problem may offer opportunities for aspects of the know-how to become explicit, e.g. the formalisation of industry procedures. Through this constant recontextualization of knowledge by a practitioner over time becomes specific to him/her.

\section{Conclusion}

This chapter studied the working and learning of teachers' professional/occupational practices. The conceptual framework used Bernstein's recontexualization as a platform for delineating these micro-practices. The framework draws on post-Bernsteinian researchers to illuminate these complex practices and at the same time expanding and developing the definition of knowledge to include theoretical know-how, experiences, abilities, capacities and skill sets. The framework offered two types of recontextualization processes: Content Recontexualization and Occupational Recontextualization. In so doing, the contributions of this chapter include a theoretical framework to understanding the micro-workings of a vocational practitioner, a wider perspective of knowledge, and the use of real-life examples of vocational areas to illustrate the practitioners' activities.

These contributions have implications for the education of vocational teachers, the areas for qualified teachers' continuous professional development (CPD), and the support structures to mentoring and professionalising vocational/occupational teacher educators and lecturers.

For FE teachers, the training in the sector in England is at present under-developed and inconsistent (Loo, 2014). An issue concerning the training of lecturers surrounds disciplinary teaching, where a generic teacher training is more the norm. The findings from this chapter highlight the need for vocational teachers to understand uncontested and ill-defined terms like teacher knowledge, vocational education and training and vocational pedagogy (Loo, 2018). Included in a teacher education programme should be opportunities to study the evidence-informed findings on topics (such as teacher know-how, choice of pedagogic strategies, and understanding of teacher knowledge applications). Where possible, there should be offers of action research opportunities (perhaps as part of a separate module) to pursue a trainee's interest. Perhaps more significantly, the trainee teachers should understand how to integrate disciplinary and pedagogic know-how. Loo (2013) used multimodality (Kress, 2010) and reflective peer-reviewed (Pollard et al., 2008) to offer a '360-degree' training experience using digital recordings of teaching sessions. Multimodality is used to analyse the different modes (e.g. visual imagery, sound and text) of the digital recordings (Kress, 2010). The reflective peer review is applied to offer a supportive and constructive dimension to evaluate the recorded teaching sessions in a collaborative context within a sociocultural environment (Loo, 2013, p. 501). Through these opportunities, trainee teachers have the opportunities to analysis, discuss and inform each other the subtleties of 
teaching, the mutability of disciplinary, pedagogic, occupational and real-life knowhow (both explicit and tacit forms), and the symbiotic relationships between teaching and occupational practices (Loo, 2014).

Regarding their CPD, one needs to be aware of the possible tensions in CPD provisions. One tension is for teaching institutions to offer generic or specific offers. Generic ones could include administrative aspects relating to teachers' requirements such as adherence to particular institutional systems and teaching styles such as the use of smart boards and technological tools e.g. Socrative software. Specific CPD offers relate to the teachers' related occupational areas such as equine studies and gas fitting industry. These CPD provisions might include teaching strategies that are relevant to the delivery of these occupational areas. These teachers would also need to keep in touch with their occupational practices. These could include spending time at the occupational organisations (industrial placements), attending trade and professional conferences and related events, and subscribing to related publications. Linking to this generic and specific tension is the delivery of these provisions either internally or externally. The constraints such as expertise, resource (financial and non-financial) and temporal would need to be taken into account. The third tension revolves around pedagogic and occupational considerations. As these vocational lecturers require the two areas of professional updating, consideration should be given to offer a balanced approach. As the deliverers work in a teaching organization, the vocational needs might not be fully appreciated by the management, which could be a cause of conflict. One possible solution is to appoint industry experts on the CPD panel to oversee staff development. This panel of external experts drawing from education, industry and lay members might ensure that the needs of the staff are met. So far, the foci have been on teaching staff. However, there will be those who are in positions of responsibility where managerial and leadership abilities are needed. So, the final tension for CPD requirements relates to managerial and leadership provisions. Questions concerning the actual subject areas, and delivery by external or internal experts need resolving.

Finally, teacher educators also require similar CPD and supporting structures to enable them to update their relevant occupational expertise. One has to bear in mind the specific nature of these educators. They are very likely to be former teachers in the sector with varied disciplinary expertise. Their roles are to provide a training programme to a diverse group of FE teachers where over 70 percent of its provisions are vocational. It appears that they have three dimensions to their roles: as vocational practitioners, lecturers of vocational programmes, and teacher trainers. Currently, there are no accredited pathways to becoming teacher educators. One possible route is to undertake action research in their disciplinary or pedagogic field via a doctoral programme. Their exposure to the investigations of education and occupational theories regarding teacher training would hone their powers of research methodologies, judgement and critical analysis. As there are gaps in teacher education in the FE sector, there is much to be gained by this approach. However, there might be other approaches such as a programme with specific modules for these educators in areas such as teaching knowledge, curriculum development, and generic and subject-specific teaching approaches.

\section{References}

Barnett M (2006) Vocational knowledge and vocational pedagogy. In: Young M and 
Gamble J (Eds) Knowledge, Curriculum and Qualifications for South African Further Education. Cape Town, Human Sciences Research Council Press, p 143-158

Becher T (1994) The Significance of Disciplinary Differences. Studies in Higher Education, 19: 151-161

Bernstein B (1996) Pedagogy, Symbolic Control and Identity: Theory, Research, Critique. London, Taylor and Francis Limited

Chaiklin S, Lave J (1996) Understanding practice: Perspectives on activity and context. Cambridge, Cambridge University Press

Cole M (1996) Cultural Psychology: A Once and Future Discipline. Cambridge, Massachusetts, USA, The Belknap Press of Harvard University Press

Clarke L, Winch C (2004) Apprenticeship and Applied Theoretical Knowledge. Educational Philosophy and Theory: Incorporating ACCESS, 36(5): 509-521

Collins H (2010) Tacit and Explicit Knowledge. Chicago, University of Chicago Press

Education and Training Foundation (ETF) (2014) Professional Standards for Teachers and Trainers in England. London, ETF

Eraut M (2004) Transfer of knowledge between education and workplace settings. In: Rainbird H, Fuller A and Munro A (Eds) Workplace Learning in Context. London, Routledge, p 201-221

Evans K (2016) Higher vocational learning and knowledgeable practice: The newly qualified practitioner at work. In: Loo S and Jameson J (Eds) Vocationalism in Further and Higher Education: Policy, Programmes and Pedagogy. Abingdon, Routledge, $p$ $117-130$

Evans K, Guile D, Harris J, Allan H (2010) Putting knowledge to work: A new approach. Nurse Education Today, 30(3): 245-251

Frontier Economics Limited (2014) Further Education workforce data for England: Analysis of the 2012-2013 staff individualized record data. London, Frontier Economics Limited

Hager P (2004) Front-loading, Workplace Learning and Skill Development. Educational Philosophy and Theory: Incorporating ACCESS, 36(5): 523-534

Handal G (1999) Consultation Using Critical Friends. New Directions for Teaching and Learning, 79, 59-70

Kahneman D (2012) Thinking, Fast and Slow. London, Penguin Books

Kemmis, R B, Green A (2013) Vocational education and training teachers' conceptions of their pedagogy. International Journal of Training Research, 11(2): 101-121 
Kemmis S, Grootenboer P (2008) Situating praxis in practice: Practice architectures and the cultural, social and material conditions for practice. In: Kemmis S, and Smith TJ (Eds) Enabling praxis: Challenges for education, Rotterdam, The Netherlands, Sense, p 37-62

Kress G 2010 Multimodality: A Social Semiotic Approach to Contemporary Communication. London, Routledge

Loo S (2012) The application of pedagogic knowledge to teaching: A conceptual framework. International Journal of Lifelong Education 31(6): 705-723

Loo S (2013) Professional development of teachers: using multimodality and reflective peer review approaches to analyse digitally recorded teaching practices. Teacher Development: An international journal of teachers' professional development, 17(4): 499-517

Loo S (2014) Placing 'knowledge' in teacher education in the English Further Education teaching sector: an alternative approach based on collaboration and evidence based research. British Journal of Educational Studies, 62(3): 337-354

Loo S (2018) Teachers and Teaching in Vocational and Professional Education. Abingdon, Routledge

Loo S, Jameson J (2017) Introduction: Vocationalism in the English Context. In: Loo $\mathrm{S}$, Jameson $\mathrm{J}$ (Eds) Vocationalism in Further and Higher Education: Policy, Programmes and Pedagogy, Abingdon, Routledge, p 1-6

Nonaka I, Takeuchi H (1995) The Knowledge Creating Company: How Japanese Companies Create the Dynamics of Innovation. New York, Oxford University Press

Polanyi M (1966) The Tacit Dimension. London, Routledge and Kegan Paul

Pollard A, Anderson A,Maddock M, Swaffield S, Warin J, Warwick P 2008

Reflective Teaching: Evidence-Informed Professional Practice. London, Continuum

Robson C (2002) Real World Research: A Resource for Social Scientists and Practitioner-Researchers. Oxford, Blackwell Publishing

Smeby J-C (1996) Disciplinary Differences in University Teaching. Studies in Higher Education, 21: 69-79

United Nations Educational, Scientific and Culture Organization (UNESCO) (2012) Building Skills for Work and Life. $3^{\text {rd }}$ UNESCO TVET Congress, Shanghai, 16 May

Winch C (2014) Know-how and knowledge in the professional curriculum. In: Young M, Muller J (Eds) Knowledge, Expertise and the Professions, London, Routledge, p 4760

\section{Appendix}


Table 1 - Details of participants

\begin{tabular}{|c|c|c|c|c|}
\hline $\begin{array}{l}\text { Participant } \\
\text { Gender } \\
\text { Age }\end{array}$ & $\begin{array}{l}\text { Teaching } \\
\text { institutions } \\
\text { Level of } \\
\text { academic } \\
\text { qualifications }\end{array}$ & $\begin{array}{l}\text { Full-time/Part-time } \\
\text { Years of teaching } \\
\text { experience }\end{array}$ & $\begin{array}{l}\text { Disciplinary } \\
\text { areas }\end{array}$ & $\begin{array}{l}\text { Occupational/ } \\
\text { life experiences }\end{array}$ \\
\hline
\end{tabular}

\begin{tabular}{|c|c|c|c|c|}
\hline $\begin{array}{l}\text { P1 } \\
\text { Female } \\
40 s\end{array}$ & $\begin{array}{l}\text { FE college } \\
\text { Level } 4\end{array}$ & $\begin{array}{l}\text { Full-time } \\
7 \text { years }\end{array}$ & Travel and tourism & $\begin{array}{l}\text { Worked in the } \\
\text { airline industry as } \\
\text { part of a cabin } \\
\text { crew for } 8 \text { years }\end{array}$ \\
\hline $\begin{array}{l}\text { P2 } \\
\text { Male } \\
50 \mathrm{~s}\end{array}$ & $\begin{array}{l}\text { FE college } \\
\text { Level } 4\end{array}$ & $\begin{array}{l}\text { Full-time } \\
15 \text { years }\end{array}$ & Gas services & $\begin{array}{l}\text { Worked in the gas } \\
\text { service industry as } \\
\text { an engineer and as } \\
\text { trainer and } \\
\text { assessor }\end{array}$ \\
\hline $\begin{array}{l}\text { P3 } \\
\text { Female } \\
50 \mathrm{~s}\end{array}$ & $\begin{array}{l}\text { FE college } \\
\text { Level } 5\end{array}$ & $\begin{array}{l}\text { Full-time } \\
8 \text { years }\end{array}$ & $\begin{array}{l}\text { Health and social } \\
\text { care }\end{array}$ & $\begin{array}{l}\text { Worked as health } \\
\text { and social care } \\
\text { worker and nursery } \\
\text { nurse in the early } \\
\text { years and childcare } \\
\text { areas }\end{array}$ \\
\hline $\begin{array}{l}\mathrm{P} 4 \\
\text { Female } \\
60 \mathrm{~s}\end{array}$ & $\begin{array}{l}\text { FE college } \\
\text { Level } 5\end{array}$ & $\begin{array}{l}\text { Full-time } \\
13 \text { years } \\
\text { (6 years in } \\
\text { HEIs) } \\
\text { Currently } 0.6\end{array}$ & $\begin{array}{l}\text { Art and design } \\
\text { Fashion and } \\
\text { textiles }\end{array}$ & $\begin{array}{l}\text { Worked in banking } \\
\text { and retail (craft } \\
\text { and museums) } \\
\text { Currently working } \\
\text { as a fashion } \\
\text { designer }\end{array}$ \\
\hline $\begin{array}{l}\text { P5 } \\
\text { Male } \\
40 \mathrm{~s}\end{array}$ & $\begin{array}{l}\text { FE college } \\
\text { Level } 4\end{array}$ & $\begin{array}{l}\text { Full-time } \\
3.5 \text { years } \\
(4 \text { years } \mathrm{p}-\mathrm{t})\end{array}$ & Equine studies & $\begin{array}{l}\text { Worked and } \\
\text { performed in the } \\
\text { equine industry } \\
\text { and related } \\
\text { governing bodies }\end{array}$ \\
\hline $\begin{array}{l}\text { P6 } \\
\text { Female } \\
40 s\end{array}$ & $\begin{array}{l}\text { FE college } \\
\text { Level }\end{array}$ & $\begin{array}{l}\text { Full-time } \\
5 \text { years }\end{array}$ & Equine studies & $\begin{array}{l}\text { Worked in the } \\
\text { equine industry }\end{array}$ \\
\hline $\begin{array}{l}\text { P7 } \\
\text { Male } \\
40 \mathrm{~s}\end{array}$ & $\begin{array}{l}\text { Adult and } \\
\text { community } \\
\text { Level } 5\end{array}$ & Part-time & $\begin{array}{l}\text { Art - painting and } \\
\text { printmaking }\end{array}$ & $\begin{array}{l}\text { Working as an } \\
\text { printmaker and } \\
\text { architect }\end{array}$ \\
\hline
\end{tabular}

